\title{
CYTOMORPHOLOGICAL STUDY OF BREAST LESIONS IN PRE-MENOPAUSAL AND POST-MENOPAUSAL WOMEN PRESENTING IN JNIMS HOSPITAL, MANIPUR: A RETROSPECTIVE STUDY
}

\author{
Rochitra Khumukcham¹, R. K. Banashree Devi², Thangjam Shitalmala Devi³, Ksh. Achouba Singh ${ }^{4}$
}

${ }_{1}^{1}$ Postgraduate Student, Department of Pathology, Jawaharlal Nehru Institute of Medical Sciences, (JNIMS), Imphal. ${ }^{2}$ Associate Professor, Department of Pathology, Jawaharlal Nehru Institute of Medical Sciences, (JNIMS), Imphal.

${ }^{3}$ Senior Resident, Department of Pathology, Jawaharlal Nehru Institute of Medical Sciences, (JNIMS), Imphal. ${ }^{4}$ Associate Professor, Department of Endocrinology, Jawaharlal Nehru Institute of Medical Sciences, (JNIMS), Imphal.

\section{ABSTRACT}

\section{BACKGROUND}

Diagnosis of a breast lump is of prime concern to the physician for proper management. The diagnostic aids come in various modalities, but Fine Needle Aspiration Cytology (FNAC) is a quick, reliable and time saving procedure to distinguish malignant from benign diseases of breast and thereby influencing the way of treatment proceeding in each case. The study gives emphasis on the distribution of various breast diseases among the pre- and post-menopausal females by using FNAC.

\section{MATERIALS AND METHODS}

Between 2012 and 2016, a total of 412 female patients presenting with breast lumps subjected to FNAC are retrospectively analysed. The study population was divided into two groups - premenopausal and post-menopausal group and the comparison of the various types of breast lesions as diagnosed by FNAC was made in the two study groups.

\section{RESULTS}

Out of the total study population, 400 were eligible out of which 337 females were pre-menopausal and 53 females were postmenopausal. Palpable breast lump was the most common presenting complaint (86.8\%) followed by mastalgia (11.5\%) and nipple discharge (7.5\%); 94\% (n=376) were benign lesions and 6\% $(n=24)$ were malignant lesions. Among the benign lesions, fibroadenoma was the most predominant lesion (53.9\%) and infiltrating ductal carcinoma was the most common malignant lesion (79.2\%).

\section{CONCLUSION}

FNAC as a diagnostic tool for breast lesions is a rapid and reliable procedure. It distinguishes benign from malignant lesions with very few cases with inconclusive findings. In pre-menopausal and post-menopausal women the lesions were mostly benign, but malignant disease occurred more commonly in post-menopausal women. Diagnosis of breast lesions with the help of FNAC helped in guiding treatment and correlation with histopathological examination of the lesion will further measure the reliability of this procedure.

\section{KEYWORDS}

FNAC, Breast Lump, Carcinoma, Ductal, Fibroadenoma.

HOW TO CITE THIS ARTICLE: Khumukcham R, Devi RKB, Devi TS, et al. Cytomorphological study of breast lesions in premenopausal and post-menopausal women presenting in JNIMS Hospital, Manipur: a retrospective study. J. Evolution Med. Dent. Sci. 2016;5(78):5820-5823, DOI: 10.14260/jemds/2016/1313

\section{BACKGROUND}

Evaluating a breast mass can be a difficult task. The patient has a fear of breast malignancy as a result of which she has lots of anxiety, and physicians may sometimes find it difficult to differentiate the mass from normal breast parenchyma. Majority of breast lesions will prove to be of a benign aetiology. Physical, psychological and financial costs of investigating benign breast diseases, primarily to exclude malignancy are substantial. The management of the patients varies according to the hospital the patient visits. Treatment facilities in different hospitals vary due to variation in the setup from Peripheral hospitals with basic facilities to the

Financial or Other, Competing Interest: None.

Submission 30-08-2016, Peer Review 20-09-2016,

Acceptance 23-09-2016, Published 29-09-2016.

Corresponding Author:

Dr. Ksh. Achouba Singh

Uripok Bachaspati Maning Leikai,

Imphal-795001, Manipur.

E-mail: drachoubasingh@yahoo.com

DOI: $10.14260 /$ jemds/2016/1313 specialised institutions in the higher centres with all specialists, medical oncologists, radiation oncologists, surgical oncologists and other supporting facilities. Treatment in peripheral hospitals is usually a radical mastectomy with or without radiotherapy. But in specialised cancer institutions, management follows international recommendations, viz. brachiocephalic trunk or modified radical mastectomy, radiation therapy and chemotherapy.[1]

Fine-Needle Aspiration Cytology (FNAC) method was introduced as a primary test in the diagnosis of breast carcinoma. FNAC is not only useful in diagnosis and further planning of treatment without need for biopsy, but also helpful in prognostication of the tumour by helping in estimating nuclear grading, mitotic index, hormone receptor status and DNA contents.[2] Techniques used to diagnose breast lesions include clinical breast examination, breast imaging and breast cytology.[3,4] Fine-needle aspiration cytology is the most reliable component of this triple test assessment of breast lesions due to its accurate negative predictive value and positive predictive value. ${ }^{[5,6]} \mathrm{A}$ histologic study of 1501 breast specimens conducted by Bjerregaard 
and Kung'u found that benign and malignant lesions accounted for $72.2 \%$ and $27.8 \%$ of the diagnosed breast lesions, respectively.[7] A retrospective study of 1172 patients performed by Otieno et al found that fibroadenoma (33.2\%) and ductal carcinoma $(17.4 \%)$ were the most commonly diagnosed types of lesions and $98.9 \%$ of all breast lesions occurred in female patients.[8] Fine Needle Aspiration Cytology (FNAC) is a safe, reliable and time saving outdoor procedure with little discomfort to the patient. FNAC is useful in diagnosis. The study was carried out with the aim of studying the frequency of various breast lesions on FNAC in patients presenting in JNIMS Hospital, Manipur.

\section{MATERIALS AND METHODS}

Medical records in the form of breast cytology reports from 412 consecutive patients presenting to Breast or General Surgical Clinics at JNIMS and over the period of four and a half years from January 2, 2012 to June 6, 2016 were studied. The study population is divided into two groups - premenopausal and post-menopausal age group. Patients presented with palpable breast lump, nipple discharge, breast pain, nipple retraction, skin changes or palpable axillary lymph nodes were accessed from the records of Department of JNIMS's Cytology Laboratory and examined for eligibility. Reports having patient age and sex, clinical summary, sampling technique, microscopic findings and conclusive diagnosis were included in the study. Reports having major typographical errors, cytological diagnosis of secondary breast diseases and inconclusive breast cytology results were excluded from the study. Appropriate approval of the Institutional Ethical Committee, JNIMS, was obtained for the same. All data were analysed by Chi Square test using Microsoft Excel 2013.

\section{RESULTS}

A total of 400 breast cytology reports satisfied eligibility criteria. The study population were in the age group (14-80) yrs. of age. Reports are classified into pre-menopausal and post-menopausal age groups. The pre-menopausal population was in the age group (14-42) yrs. of age. The postmenopausal population was in the age group (42-80) yrs. of age. The presenting complaints are summarised in Table 1. Palpable breast lump was the most common complaint $(n=347)$, while palpable axillary lymph node(s) was the least common $(\mathrm{n}=2)$.

\begin{tabular}{|c|c|c|}
\hline $\begin{array}{c}\text { Sl. } \\
\text { No. }\end{array}$ & $\begin{array}{c}\text { Signs and } \\
\text { Symptoms }\end{array}$ & $\begin{array}{c}\text { Total No. } \\
\text { of Cases }\end{array}$ \\
\hline 1 & Palpable breast lump & $347(86.8 \%)$ \\
\hline 2 & Nipple discharge & $30(7.5 \%)$ \\
\hline 3 & Breast pain & $46(11.5 \%)$ \\
\hline 4 & Skin changes & $12(3.0 \%)$ \\
\hline 5 & $\begin{array}{c}\text { Palpable axillary } \\
\text { lymph node(s) }\end{array}$ & $2(0.5 \%)$ \\
\hline 6 & Nipple retraction & $4(1 \%)$ \\
\hline \multicolumn{2}{|c|}{ Table 1: Presenting Complaints of Study } \\
Populations (n=400)
\end{tabular}

\begin{tabular}{|c|c|c|c|}
\hline $\begin{array}{c}\text { Menopausal } \\
\text { Status }\end{array}$ & \multicolumn{2}{|c|}{ Lesion Type } & P-Value \\
\cline { 2 - 3 } & Benign, N (\%) & Malignant, N (\%) & 0.001 \\
$\begin{array}{c}\text { Pre- } \\
\text { menopausal }\end{array}$ & $329(97.6)$ & $8(2.4)$ & \\
\hline $\begin{array}{c}\text { Post- } \\
\text { menopausal }\end{array}$ & $47(4.6)$ & $16(25.4)$ & \\
\cline { 1 - 3 } & \multicolumn{2}{|c|}{ Table 2: Comparison of Lesion Type with } \\
Menopausal Status (N=400) & \\
\hline
\end{tabular}

The frequency distribution of all diagnosed breast lesions is shown in the Table 2 and Table 3. Fibroadenoma $(n=203)$ and benign proliferative breast disease $(n=40)$ were the most frequently diagnosed benign breast lesions, whereas ductal carcinoma $(n=19)$ was the most frequently diagnosed malignant breast lesion. Other frequently diagnosed breast lesions include fibrocystic breast disease ( $n=33)$, inflammatory breast lesions $(n=23)$, sub-areolar abscess $(n=17)$, galactocele $(n=13)$, lactation changes $(n=14)$.

\begin{tabular}{|c|c|c|c|}
\hline $\begin{array}{c}(\mathrm{A}) \\
\text { Benign and } \\
\text { Inflammatory } \\
\text { Lesions } \\
\end{array}$ & $\begin{array}{l}\text { Pre- } \\
\text { Menopausal } \\
(n=329)\end{array}$ & $\begin{array}{l}\text { Post- } \\
\text { Menopausal } \\
(n=47)\end{array}$ & $\begin{array}{c}\text { Total } \\
(n=376)\end{array}$ \\
\hline Fibroadenoma & $\begin{array}{c}193 \\
(58.6 \%) \\
\end{array}$ & $\begin{array}{c}10 \\
(21.3 \%) \\
\end{array}$ & $\begin{array}{c}203 \\
(53.9 \%) \\
\end{array}$ \\
\hline $\begin{array}{c}\text { Fibrocystic } \\
\text { disease }\end{array}$ & $\begin{array}{c}23 \\
(7.0 \%) \\
\end{array}$ & $\begin{array}{c}10 \\
(21.3 \%) \\
\end{array}$ & $\begin{array}{c}33 \\
(8.8 \%) \\
\end{array}$ \\
\hline $\begin{array}{l}\text { Fibrocystic dx } \\
\text { with lactational } \\
\text { change }\end{array}$ & $\begin{array}{c}2 \\
(0.6 \%)\end{array}$ & $\begin{array}{c}0 \\
(0 \%)\end{array}$ & $\begin{array}{c}2 \\
(0.5 \%)\end{array}$ \\
\hline Duct ectasia & $\begin{array}{c}0 \\
(0 \%) \\
\end{array}$ & $\begin{array}{c}5 \\
(10.6 \%) \\
\end{array}$ & $\begin{array}{c}5 \\
(1.3 \%) \\
\end{array}$ \\
\hline $\begin{array}{l}\text { Atypical ductal } \\
\text { hyperplasia }\end{array}$ & $\begin{array}{c}8 \\
(2.4 \%) \\
\end{array}$ & $\begin{array}{c}4 \\
(8.5 \%) \\
\end{array}$ & $\begin{array}{c}12 \\
(3 \%)\end{array}$ \\
\hline $\begin{array}{l}\text { Benign } \\
\text { proliferative } \\
\text { breast disease }\end{array}$ & $\begin{array}{c}33 \\
(10.0 \%)\end{array}$ & $\begin{array}{c}7 \\
(14.8 \%)\end{array}$ & $\begin{array}{c}40 \\
(10.6 \%)\end{array}$ \\
\hline $\begin{array}{l}\text { Benign } \\
\text { phyllodes } \\
\text { tumour }\end{array}$ & $\begin{array}{c}3 \\
(0.9 \%)\end{array}$ & $\begin{array}{c}2 \\
(4.2 \%)\end{array}$ & $\begin{array}{c}5 \\
(1.3 \%)\end{array}$ \\
\hline Galactocele & $\begin{array}{c}13 \\
(3.9 \%) \\
\end{array}$ & $\begin{array}{c}0 \\
(0 \%) \\
\end{array}$ & $\begin{array}{c}13 \\
(3.4 \%) \\
\end{array}$ \\
\hline $\begin{array}{l}\text { Lactational } \\
\text { change }\end{array}$ & $\begin{array}{c}14 \\
(4.2 \%)\end{array}$ & $\begin{array}{c}0 \\
(0 \%) \\
\end{array}$ & $\begin{array}{c}14 \\
(3.7 \%) \\
\end{array}$ \\
\hline $\begin{array}{l}\text { Benign cystic } \\
\text { lesion }\end{array}$ & $\begin{array}{c}6 \\
(1.8 \%)\end{array}$ & $\begin{array}{c}0 \\
(0 \%)\end{array}$ & $\begin{array}{c}6 \\
(1.5 \%)\end{array}$ \\
\hline $\begin{array}{l}\text { Lactating } \\
\text { adenoma }\end{array}$ & $\begin{array}{c}2 \\
(0.6 \%) \\
\end{array}$ & $\begin{array}{c}0 \\
(0 \%) \\
\end{array}$ & $\begin{array}{c}2 \\
(0.5 \%) \\
\end{array}$ \\
\hline Fat necrosis & $\begin{array}{c}1 \\
(0.3 \%)\end{array}$ & $\begin{array}{c}0 \\
(0 \%)\end{array}$ & $\begin{array}{c}1 \\
(0.3 \%)\end{array}$ \\
\hline $\begin{array}{l}\text { Sub-areolar } \\
\text { abscess }\end{array}$ & $\begin{array}{c}11 \\
(3.3 \%)\end{array}$ & $\begin{array}{c}6 \\
(12.8 \%) \\
\end{array}$ & $\begin{array}{c}17 \\
(4.5 \%)\end{array}$ \\
\hline $\begin{array}{l}\text { Inflammatory } \\
\text { breast lesions }\end{array}$ & $\begin{array}{c}20 \\
(6.1 \%)\end{array}$ & $\begin{array}{c}3 \\
(6.3 \%)\end{array}$ & $\begin{array}{c}23 \\
(6.1 \%)\end{array}$ \\
\hline \multicolumn{4}{|c|}{$\begin{array}{c}\text { Table 3: Types of Diagnosed Benign Breast Lesions and } \\
\text { Distribution in Pre-Menopausal and } \\
\text { Post-Menopausal Populations }\end{array}$} \\
\hline
\end{tabular}

\begin{tabular}{|c|c|c|c|}
\hline $\begin{array}{c}\mathbf{( B )} \\
\text { Malignant } \\
\text { Lesions }\end{array}$ & $\begin{array}{c}\text { Pre- } \\
\text { Menopausal } \\
\text { (n=8) }\end{array}$ & $\begin{array}{c}\text { Post- } \\
\text { Menopausal } \\
\text { (n=16) }\end{array}$ & $\begin{array}{c}\text { Total } \\
\mathbf{( 2 4 )}\end{array}$ \\
\hline $\begin{array}{c}\text { Infiltrating } \\
\text { ductal } \\
\text { carcinoma }\end{array}$ & $4(50.0 \%)$ & $16(100 \%)$ & $\begin{array}{c}19(79.2 \\
\%)\end{array}$ \\
\hline $\begin{array}{c}\text { Medullary } \\
\text { carcinoma }\end{array}$ & $3(37.5 \%)$ & $0(0 \%)$ & $\begin{array}{c}3(12.5 \\
\%)\end{array}$ \\
\hline $\begin{array}{c}\text { Mucinous } \\
\text { colloid) } \\
\text { carcinoma }\end{array}$ & $1(12.5 \%)$ & $0(0 \%)$ & $1(4.2 \%)$ \\
\hline
\end{tabular}

Table 4: Types of Diagnosed Malignant Breast Lesions and Distribution in Pre-Menopausal and Post-Menopausal Populations

Of the 400 diagnosed breast lesions, 94\% (n=376) were benign lesions (with inflammatory lesions), 6\% ( $n=24)$ were malignant lesions. Thus, benign-to-malignant ratio is 15.6:1.

Total number of cases in premenopausal population is 338 and in postmenopausal population are 62. The distribution of breast lesions diagnosed by breast cytology in pre-menopausal and post-menopausal populations reflects 
that benign and inflammatory lesions is $330(n=330)$ in premenopausal population and $46(n=46)$ in post-menopausal population. Malignant lesions in premenopausal population is $8(n=8)$ and post-menopausal population is $16(n=16)$.

Inflammatory lesions in pre-menopausal population is found in 31 cases and 9 cases in post-menopausal population. of the benign lesions in pre-menopausal population, fibroadenoma $(n=193)$ and benign proliferative breast disease $(n=33)$ were the most common cases as compared to fibrocystic disease $(n=10)$ and inflammatory breast lesion $(n=9)$ in post-menopausal group.

of the malignant lesions in pre-menopausal population $(n=8)$, infiltrating ductal carcinoma $(n=4)$ and medullary carcinoma $(n=3)$ are the most common, while mucinous (colloid) carcinoma have one $(n=1)$ case only. In postmenopausal population out of the $16(n=16)$ malignant cases, all the cases were found to be of infiltrating ductal carcinomas.

\section{IMAGING SPECTRUM OF THE LESIONS FIGURE 1 TO 6}

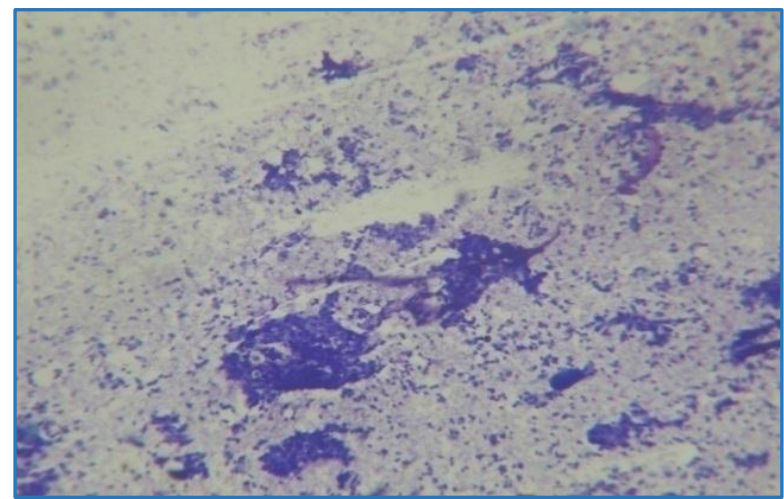

Fig. 1: Fibroadenoma May-Grunwald Giemsa Stain

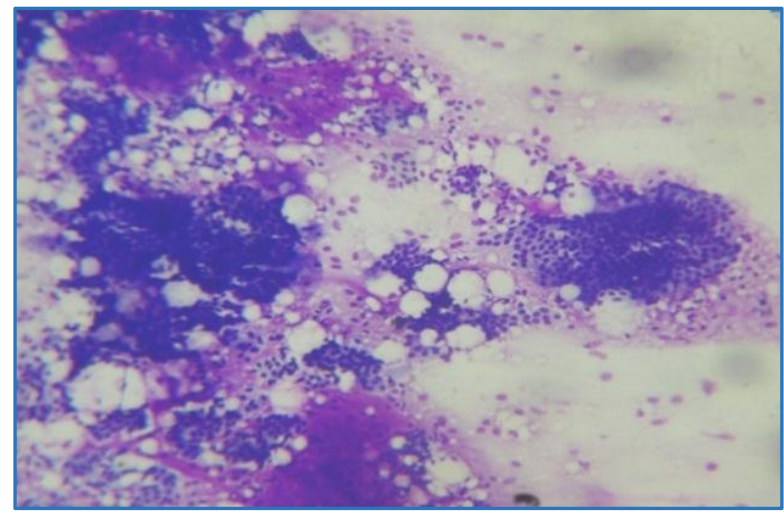

Fig. 2: Fibroadenoma with Cystic Degeneration, May-Grunwald Giemsa

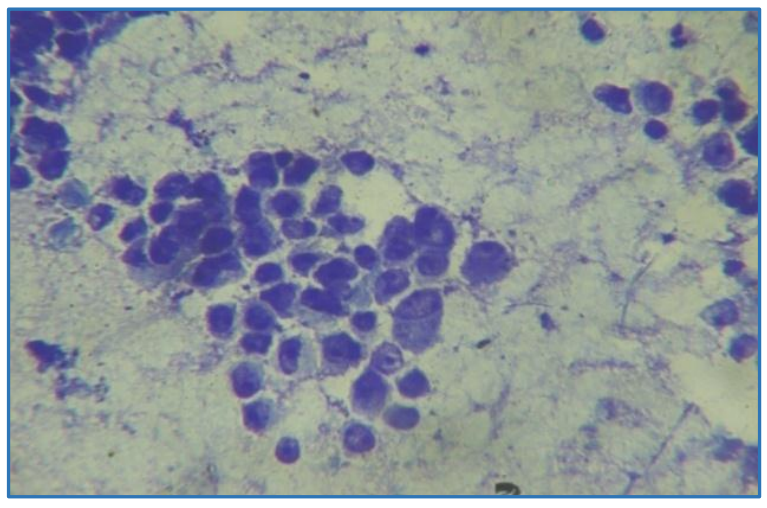

Fig. 3: Infiltrating Ductal Carcinoma May-Grunwald Giemsa

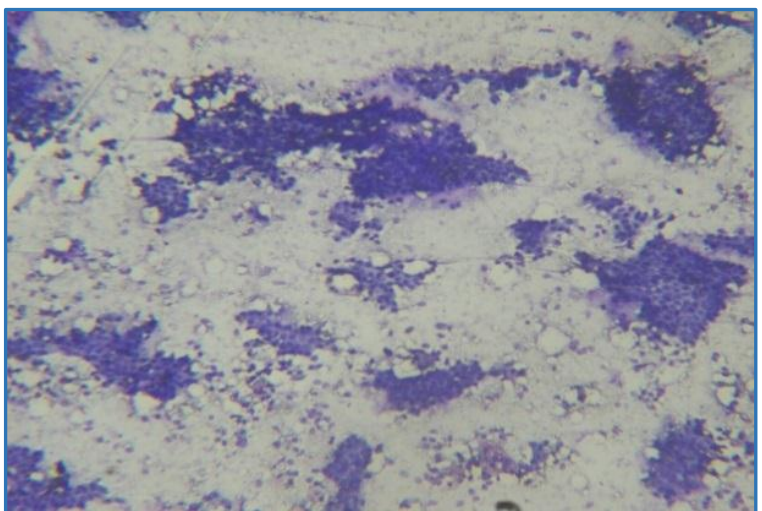

Fig. 4: Cellular Fibroadenoma May-Grunwald Giemsa

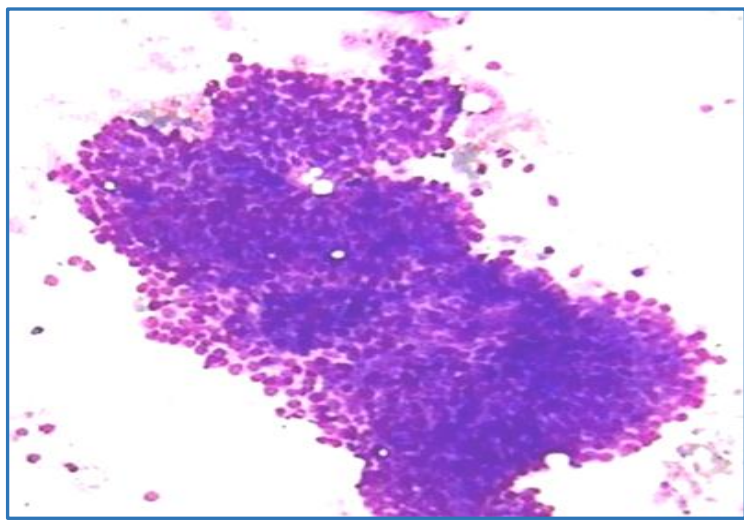

Fig. 5: Fibroadenoma with Epithelial Hyperplasia, May-Grunwald Giemsa

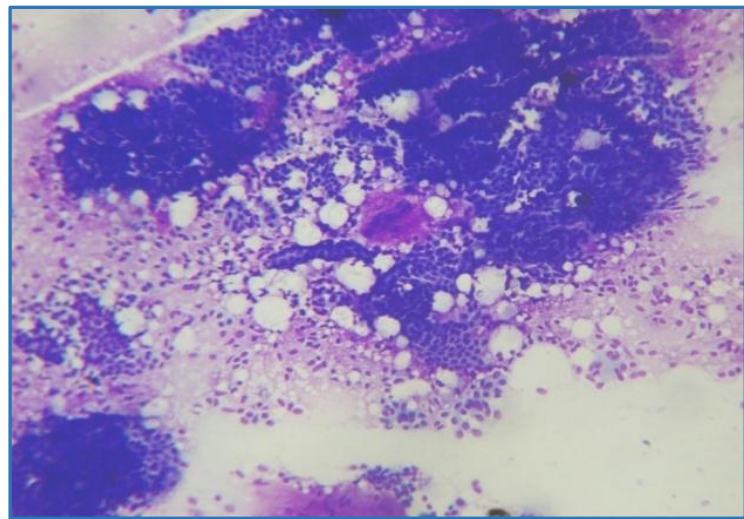

Fig. 6: Atypical Ductal Hyperplasia, May-Grunwald Giemsa

\section{DISCUSSION}

The main objective of the present study was to determine the type and distribution of breast lesions diagnosed by breast cytology in patients presenting at JNIMS Hospital. Of the total 400 cases, benign cases were found to be 376 and malignant cases were 24 .

Of the total diagnosed breast lesions $94 \%$ were benign, which is in agreement with findings by Bjerregaard and Kung'u[7] and Panjvani et al.[9] Fibroadenoma was the most frequently diagnosed lesion in pre-menopausal women, consistent with both prospective and retrospective studies from India,[9] Uganda[10] and Pakistan.[11] Whereas in study by Tiwari[12] and Qasim et al[13] fibroadenoma (56.25\% and $82.14 \%$ ) followed by mastitis/breast abscess $(20.31 \%$ and 
$10.71 \%)$ and fibrocystic disease $(7.81 \%$ and $3.57 \%)$ were the most common breast lesions. Palpable breast lump (347 patients) was the most common presenting complaint, which is consistent with previous findings in Kenya[14] and elsewhere. [3,11,15]

The other objective of the present study was to determine the type of lesions found in pre- and post-menopausal population. Benign lesions were $97.6 \%$ in pre-menopausal, while in post-menopausal benign lesions were $74.2 \%$. Malignant lesions were more prevalent in post-menopausal population $(25.8 \%)$ than in pre-menopausal population $(2.4 \%)$. Of the malignant lesions, infiltrating ductal carcinoma was the most common case found in post-menopausal population $(100 \%)$, while in pre-menopausal population, prevalence are found to be infiltrating ductal carcinoma $(50 \%)$ and medullary carcinoma (37.5\%). Infiltrating ductal carcinoma was most common in the present study with 20 $(83.3 \%)$ cases in present study and $141(95.91 \%)$ in study by Domínguez et al.[16]

The statistical analysis of the study was done using ChiSquare test. The $\mathrm{p}$ value was found to be 0.001 and was found to be statistically significant.

\section{CONCLUSION}

Fine-needle aspiration cytology is a rapid and effective method. It is useful for primary categorisation of palpable breast lumps into benign, malignant, atypical, suspicious and unsatisfactory categories. Benign breast lesions are common than malignant lesions, in benign disease fibroadenoma and fibrocystic disease are more common, whereas of malignant lesions infiltrating ductal carcinoma accounts for the highest number.

\section{Limitations of the Study}

The paucity of the histopathology samples sent to our department was the main limiting factor for the present study and histopathological correlation could not be performed.

\section{REFERENCES}

1. Chopra R. The Indian scene. J Clin Oncol 2001;19(Suppl 18):106S-111S.

2. Meena SP, Hemrajani DK, Joshi N. A comparative and evaluative study of cytological and histological grading system profile in malignant neoplasm of breast-an important prognostic factor. Indian J Pathol Microbiol 2006;49(2):199-202.
3. Salzman B, Fleegle S, Tully AS. Common breast problems. Am Fam Physician 2012;86(4):343-9.

4. Morris A, Pommier RF, Schmidt WA, et al. Accurate evaluation of palpable breast masses by the triple test score. Arch Surg 1998;133(9):930-4.

5. Ngotho J, Githaiga J, Kaisha W. Palpable discrete breast masses in young women: two of the components of the modified triple test may be adequate. S Afr J Surg 2013;51(2):58-60.

6. Muchiri LW, Penner DW, Adwok J, et al. Role of fineneedle aspiration biopsy in the diagnosis of breast lumps at the Kenyatta national hospital. East Afr Med J 1993;70(Suppl4):31-3.

7. Bjerregaard B, Kung'u A. Benign breast lesions in Kenya: a histological study. East Afr Med J 1992;69(5):231-5.

8. Otieno ES, Kimende SK, Micheni J. The pattern of breast diseases at Kenyatta national hospital. Annals African Surgery 2008;2:97-101.

9. Panjvani SI, Parikh BJ, Parikh SB, et al. Utility of fine needle aspiration cytology in the evaluation of breast lesions. J Clin Diagn Res 2013;7(12):2777-9.

10. Okoth C, Galukande $M$, Jombwe J, et al. Benign proliferative breast diseases among female patients at a sub-Saharan Africa tertiary hospital: a cross sectional study. BMC Surg 2013;13:9.

11. Aslam HM, Saleem S, Shaikh HA, et al. Clinicopathological profile of patients with breast diseases. Diagn Pathol 2013;8:77.

12. Tiwari M. Role of fine needle aspiration cytology in diagnosis of breast lumps. Kathmandu Univ Med J 2007;5(2):215-7.

13. Qasim M, Ali J, Akbar SA, et al. Lump breast: role of FNAC in diagnosis. Prof Med J 2009;16:235-8.

14. Otieno ES, Micheni JN, Kimende SK, et al. Delayed presentation of breast cancer patients. East Afr Med J 2010;87(4):147-50.

15. Walker S, Hyde C, Hamilton W. Risk of breast cancer in symptomatic women in primary care: a case-control study using electronic records. $\mathrm{Br}$ J Gen Pract 2014;64(629):e788-e93.

16. Domínguez F, Riera JR, Tojo S, et al. Fine needle aspiration of breast masses. An analysis of 1,398 patients in a community hospital. Acta Cytol 1997;41(2):341-7. 